\title{
Pengaruh Scientific Approach Berbantuan Penilaian Formatif terhadap Motivasi Belajar dan Hasil Belajar Fisika Siswa Kelas XI pada Materi Elastisitas
}

\author{
Sabilal Rosyad ${ }^{1}$, Markus Diantoro ${ }^{1}$, Sentot Kusairi ${ }^{1}$ \\ ${ }^{1}$ Pendidikan Fisika-Universitas Negeri Malang
}

\begin{tabular}{l} 
INFO ARTIKEL \\
\hline Riwayat Artikel: \\
Diterima: $30-11-2018$ \\
Disetujui: $19-10-2020$ \\
\hline
\end{tabular}

\section{Kata kunci:}

scientific approach; motivation to learn; physics learning outcomes; scientific approach; motivasi belajar; hasil belajar fisika

\begin{abstract}
ABSTRAK
Abstract: This study aims to determine the effect of the application of a scientific approach assisted by formative assessment of the motivation and results of physics learning students of class XI. The study used a quasi-experimental research design. The study involved 69 students of class XI. The experimental group received treatment in the form of a scientific approach with formative assessment, while the control class used the lecture method varied with assessment in the form of group assignments. The research instrument used a questionnaire to measure learning motivation and multiple choice tests to measure learning outcomes. The results showed that the formativeassisted approach to scientific learning models influenced learning motivation and physics learning outcomes in class XI students.

Abstrak: Penelitian ini bertujuan mengetahui pengaruh penerapan scientific approach berbantuan penilaian formatif terhadap motivasi dan hasil belajar fisika siswa kelas XI. Penelitian menggunakan rancangan penelitian eksperimen semu. Penelitian melibatkan 69 siswa kelas XI. Kelompok eksperimen mendapatkan perlakukan berupa pendekatan scientific disertai penilaian formatif, sementara kelas kontrol menggunakan metode ceramah bervariasi disertai penilaian berupa tugas kelompok. Instrumen penelitian menggunakan angket untuk mengukur motivasi belajar dan tes pilihan ganda untuk mengukur hasil belajar. Hasil penelitian menunjukkan model pembelajaran scientific approach berbantuan penilaian formatif berpengaruh terhadap motivasi belajar dan hasil belajar Fisika pada siswa kelas XI.
\end{abstract}

Alamat Korespondensi:

Sabilal Rosyad

Pendidikan Fisika

Universitas Negeri Malang

Jalan Semarang 5 Malang

E-mail: sabilalrosyad@gmail.com

Fisika adalah salah satu mata pelajaran yang merupakan ilmu yang mempunyai peran penting dalam ilmu pengetahuan dan teknologi namun sayangnya Fisika masih dianggap sebagai pelajaran yang sulit dipahami oleh siswa. Kesulitan siswa dalam belajar fisika dapat dilihat dari hasil Ujian Nasional tahun 2015, dengan nilai rata-rata Fisika SMA/MA sekota Malang sebesar 67,4 dan nilai terendah 10,3. Penyebab siswa sulit dalam mempelajari fisika adalah karena sebagian besar materi fisika terdiri dari konsep yang bersifat matematis (Istyowati, Kusairi, \& Handayanto, 2017). Hal ini juga diperkuat dengan pendapat Adeyomo (2010) menyatakan bahwa kesulitan siswa dalam memecahkan masalah matematis disebabkan karena kurangnya pengetahuan siswa dalam menghubungkan rumusan matematis dengan permasalahan fisika di kehidupan sehari-hari.

Menurut Istyowati, Kusairi, \& Handayanto (2017) menyatakan bahwa kesulitan siswa dalam belajar fisika disebabkan karena kurangnya keterampilan guru dalam menerapkan strategi pembelajaran yang tepat. Azizah, dkk (2015) dari hasil penelitianya menyatakan bahwa $88 \%$ guru masih menerapkan metode ceramah dan $22 \%$ dilakukan kegiatan praktikum. Metode ceramah oleh guru biasanya hanya berfokus pada pemberian rumus sehingga siswa cepat merasa bosan dan kurangnya penguasaan konsep/prinsip fisika (Wiyanto, 2009). Guna memecahkan masalah tersebut maka dilakukan pembelajaran fisika dengan pendekatan scientific approach. Menurut Kemendikbud (2013) bahwa pendekatan scientific approach diyakini sebagai titian emas perkembangan dan pengembangan sikap, keterampilan, dan pengetahuan peserta didik.

Nurul (2013) menyatakan bahwa scientific approach merupakan pembelajaran dengan pendekatan ilmiah dan bepusat pada siswa tanpa harus menghilangkan peranan guru sebagai peran utama dalam pembelajaran. Marjan, dkk (2014) menyatakan bahwa pembelajaran dengan scientific approach mampu meningkatkan hasil belajar siswa, dan keterampilan proses sains. Siswa mampu menemukan sendiri konsep-konsep yang dipelajari melalui proses ilmiah. In'am dan Hajar (2017) menyebutkan proses ilmiah dalam scientific approach terdiri dari kegiatan mengamati, menanya, mengumpulkan data, mengasosiasi, dan 
mempresentasikan. Kualitas pembelajaran sangat berhubungan dengan kualitas asesmen yang dilakukan guru. Guru selama ini masih kesulitan dalam melakukan penilaian terhadap sikap ilmiah siswa. Nursyarifah, dkk (2018) menyatakan bahwa sikap ilmiah dapat dicapai melalui proses ilmiah scientific approach. Kegiatan asesmen dapat membantu guru untuk mengetahui kemajuan dan kekurangan siswa selama proses pembelajaran (Kusairi, 2012). Salah satu teknik penilaian yang dapat diterapkan dalam pembelajaran scientific approach adalah penilaian formatif. Djali (2008) menyatakan bahwa penilaian formatif mampu memberikan feedback kepada siswa untuk perbaikan kegiatan belajar. Penilaian formatif sangat dianjurkan dalam kurikulum 2013 karena pelaksanakan yang singkat dan mampu memberikan feedback untuk meningkatkan proses belajar yang sesuai dengan tiga unsur, yaitu kognitif, afektif, dan psikomotor (Ismail, 2008).

Model pembelajaran Scientific Approach disertai dengan penilaian formatif dipilih sebagai salah satu upaya untuk mencapai kepaduan dalam pembelajaran mulai dari perencanaan, penggunaan metode dalam praktek pembelajaran, hingga penilaian hasil pembelajaran. Penerapan scientific approach dan penilaian formatif akan membawa dampak positif terhadap motivasi dan hasil belajar siswa dalam pembelajaran Fisika. Hamalik (2008:15) mengemukakan bahwa hasil belajar tampak sebagai terjadinya perubahan tingkah laku pada diri siswa yang dapat diamati dan diukur dalam bentuk perubahan pengetahuan, sikap, dan keterampilan. Hidayati dan Endryansyah (2014) serta Hardianti dkk (2015) menyatakan bahwa pembelajaran dengan pendekatan saintifik mampu meningkatkan hasil belajar siswa.

Selama ini, penelitian yang dilakukan oleh peneliti sebelumnya sudah banyak yang membahas tentang scientific approach. Namun Penelitian tentang perpaduan penerapan scientific approach dan penilaian formatif terhadap motivasi belajar dan hasil belajar siswa belum pernah dilakukan. Oleh karena itu, dalam penelitian ini, penerapan scientific approach dan penilaian formatif diasumsikan mampu akan membawa dampak positif terhadap motivasi dan hasil belajar siswa. Dengan demikian, jika penerapan scientific approach dan penilaian formatif itu dilaksanakan dalam pembelajaran, kemungkinan besar akan mampu membangun motivasi belajar siswa dan pada akhirnya akan mampu meningkatkan hasil belajar siswa. Untuk membuktikan hal tersebut, akan dilakukan penelitian yang mengarah pada seberapa besar pengaruh penerapan scientific approach berbantuan penilaian formatif terhadap motivasi belajar dan hasil belajar fisika siswa kelas XI perempuan pada materi Elastisitas. Tujuan dari penelitian ini adalah (1) untuk mengetahui pengaruh penerapan scientific approach berbantuan penilaian formatif terhadap motivasi belajar siswa kelas XI pada Madrasah Aliyah Negeri 1 Kota Malang; (2) untuk mengetahui pengaruh penerapan scientific approach berbantuan penilaian formatif terhadap hasil belajar siswa kelas XI pada Madrasah Aliyah Negeri 1 Kota Malang.

\section{METODE}

Jenis penelitian ini adalah penelitian kuantitatif dengan rancangan Quasi Experimental. Objek penelitian ini adalah siwa kelas XI IPA 1 dan kelas XI IPA 2 pada Madrasah Aliyah Negeri 1 Kota Malang. Sebanyak 34 siswa kelas IX IPA 1 dijadikan sebagai kelas control dan sebanyak 35 siswa kelas IX IPA 2 digunakan sebagai kelas eksperimen. Data dikumpulkan dengan menggunakan instrumen angket untuk mengukur motivasi belajar siswa dan tes pilihan berganda untuk mengukur hasil belajar siswa. Subjek penelitian yang dipakai adalah kelas XI MIPA 2 sebagai kelas eksperimen dan kelas XI MIPA 1 sebagai kelas kontrol. Teknik pengumpulan data menggunakan angket, observasi, pemberian tes, dokumentasi, dan lembar validasi.

Tabel 1. Kisi-kisi Angket Motivasi Belajar Siswa

\begin{tabular}{lll}
\cline { 2 - 3 } & \multicolumn{1}{c}{ No } & \multicolumn{1}{c}{ Indikator } \\
\cline { 3 - 3 } 2 & Attention (Perhatian terhadap Pelajaran Fisika) & $1,4,12,13,14,15,18,19,20$ \\
3 & Relevance (Relevansi) & 2,5 \\
4 & Convidence (Percaya diri) & $3,7,8,9,16,17$ \\
& Satisfaction (Kepuasan) & $6,10,11$
\end{tabular}

Metode analisis data menggunakan analisis deskriptif, gain score dan statistik inferensial. Analisis deskriptif persentase digunakan untuk mengetahui tingkat hasil belajar dan sebarannya. Statistik inferensial menggunakan analisis uji Independent $t$-test untuk menguji hipotesis.

\section{HASIL}

Berdasarkan hasil penelitian yang telah dilaksanakan di Madrasah Aliyah Negeri 1 Kota Malang menghasilkan data motivasi belajar dan hasil belajar Fisika materi Elastisitas. Gambaran umum motivasi belajar dan hasil belajar kelas eksperimen dan kelas kontrol disajikan pada tabel 2. 
Tabel 2. Hasil Analisis Deskriptif Motivasi Belajar Siswa

\begin{tabular}{clcc}
\hline Kelas & Nilai & Sebelum Pembelajaran (Pretest) & Sesudah Pembelajaran (Postest) \\
\hline \multirow{3}{*}{ Eksperimen } & Jumlah (N) & 35 & 35 \\
& St. Deviasi & 6.67 & 5.53 \\
& Rata-rata & 61.23 & 67.29 \\
\hline \multirow{3}{*}{ Kontrol } & Jumlah (N) & 34 & 34 \\
& St. Deviasi & 11.44 & 9.21 \\
& Rata-rata & 50.38 & 61.97 \\
\hline
\end{tabular}

Tabel 1 menunjukkan bahwa nilai rata-rata motivasi belajar siswa di kelas eksperimen (67.29) lebih besar dari nilai rata-rata motivasi belajar siswa di kelas control (61.97). Hasil ini menunjukkan jika motivasi belajar siswa di kelas eksperimen lebih tinggi daripada motivasi belajar belajar siswa di kelas kontrol.

Tabel 3. Gambaran Umum Hasil Belajar Siswa

\begin{tabular}{clcccc}
\hline \multicolumn{2}{c}{ Sumber Variasi } & Jumlah siswa & Nilai rata-rata & Nilai Tertinggi & Nilai Terendah \\
\hline \multirow{2}{*}{ Pretest } & Kelas Kontrol & 34 & 56.66 & 72.50 & 40.00 \\
& Kelas Eksperimen & 35 & 58.43 & 80.00 & 40.00 \\
\hline \multirow{2}{*}{ Postest } & Kelas Kontrol & 34 & 71.88 & 85.00 & 60.00 \\
& Kelas Eksperimen & 35 & 81.23 & 87.00 & 72.00 \\
\hline
\end{tabular}

Berdasarkan hasil tersebut dapat diketahui jika nilai rata-rata hasil belajar siswa pada kelas eksperimen lebih baik daripada nilai rata-rata hasil belajar siswa pada kelas control. Gain adalah selisih antara nilai postest dan pretest, gain menunjukkan peningkatan pemahaman atau penguasaan konsep siswa setelah pembelajaran dilakukan guru. Hasil uji gain score dijadikan sebagai dasar penentuan sejauh mana keefektivan pembelajaran yang dilakukan. Hasil uji gain score dapat dilihat pada tabel 4.

Tabel 4. Hasil Uji Gain Score

\begin{tabular}{ccccc}
\hline \multirow{2}{*}{ Kriteria Gain Score } & \multicolumn{2}{c}{ Kelas Eksperimen } & \multicolumn{2}{c}{ Kelas Kontrol } \\
\cline { 2 - 5 } & Frekuensi & Persentase & Frekuensi & Persentase \\
\hline Rendah & 4 & $11.43 \%$ & 14 & $41.18 \%$ \\
Sedang & 26 & $74.29 \%$ & 20 & $58.82 \%$ \\
Tinggi & 5 & $14.29 \%$ & 0 & $0 \%$ \\
\hline Jumlah & 35 & 100 & 34 & 100 \\
\hline
\end{tabular}

Kesimpulan dari hasil uji nilai gain score diatas adalah model pembelajaran dengan scientific approach berbantuan penilaian formatif berpengaruh lebih baik dalam meningkatkan hasil belajar mata pelajaran Fisika. Perhitungan statistik menggunakan analisis Independent t test guna menguji hipotesis dapat dilihat pada tabel 5.

Tabel 5. Hasil Uji Hipotesis I

\begin{tabular}{lccccc}
\hline & \multicolumn{2}{c}{ Levene's Test For Equality Variances } & \multicolumn{3}{c}{ t-Test for Equality of Means } \\
\hline & F & Sig. & t & Df & Sig. (2-tailed) \\
\hline Equal Variances assumed & 6.423 & 0.014 & -3.240 & 67 & 0.002 \\
Equal variances not assumed & & & -3.217 & 53.759 & 0.002 \\
\hline
\end{tabular}

Berdasarkan hasil analisis Independent t test diperoleh nilai signifikan kurang dari 0.05 yaitu sebesar 0.002. Maka dapat disimpulkan bahwa terdapat pengaruh model pembelajaran scientific approach berbantuan penilaian formatif terhadap motivasi belajar siswa pada mata pelajaran Fisika.

Tabel 6. Hasil Uji Hipotesis II

\begin{tabular}{lccccc}
\hline & \multicolumn{2}{c}{ Levene's Test For Equality } & \multicolumn{2}{c}{ t-Test for Equality of Means } \\
& Variances & Sig. & t & Df & Sig. (2-tailed) \\
\hline Equal Variances assumed & 7.114 & 0.010 & -5.946 & 67 & 0.000 \\
Equal variances not assumed & & & -5.919 & 60.237 & 0.000 \\
\hline
\end{tabular}


Berdasarkan hasil uji Independent Sample t-Test diperoleh nilai Asymp. Sig sebesar 0.000 karena nilai signifikan yang dihasilkan kurang dari 0.05 maka dapat disimpulkan jika model pembelajaran scientific approach berbantuan penilaian formatif berpengaruh terhadap hasil belajar siswa. Hal ini didukung dengan nilai rata-rata hasil belajar kelas eksperimen yang lebih besar dari nilai rata-rata hasil belajar kelas kontrol yang menunjukkan jika kelompok eksperimen yang diajar dengan menggunakan model pembelajaran scientific approach berbantuan penilaian formatif mempunyai hasil belajar yang lebih baik daripada kelompok kontrol yang diajar dengan metode konvensional.

\section{PEMBAHASAN}

Berdasarkan hasil uji Independent Sample T, diperoleh hasil bahwa terdapat perbedaan motivasi belajar antar siswa pada kelas yang diajar dengan menggunakan model pembelajarn scientific approach berbantuan penilaian formatif yaitu kelas eksperimen, dan kelas yang diajar dengan menggunakan metode konvensional yaitu kelas control. Selain itu, hasil analisis data pada motivasi belajar diketahui jika pada kelas eksperimen memiliki nilai rata-rata (mean) yang lebih tinggi yaitu sebesar 61.23 dibandingkan dengan nilai rata-rata (mean) motivasi belajar pada kelas control sebesar 50.38.

Motivasi belajar siswa pada kelas eksperimen yang menggunakan model pembelajaran scientific approach berbantuan penilaian formatif lebih tinggi daripada motivasi belajar siswa pada kelas control yang menggunakan model pembelajaran konvensional dapat dimungkinkan karena metode konvensional yang digunakan pada kelas control dirasakan kurang menarik dan cenderung monoton, selain itu siswa juga harus benar-benar menyimak penjelasan dari guru agar dapat memahami apa yang disampaikan. Pada kelas eksperimen yang menggunakan model pembelajaran scientific approach berbantuan penilaian formatif siswa dilibatkan secara aktif dalam proses pembelajaran. Hal ini dapat menyebabkan siswa lebih teratrik dalam mengikuti proses pembelajaran dengan menggunakan pembelajarn scientific approach, sehingga mendorong motivasi belajar lebih baik.

Pada kelas eksperimen yang menggunakan model pembelajaran scientific approach, siswa terkesan tertarik dengan aktivitas yang dilakukan. Keterlibatan siswa secara aktif dapat menarik perhatian siswa, sehingga siswa terdorong untuk memperhatikan materi yang disajikan guru sehingga rara siswa terkesan menikmati pelajaran. Hal ini dapat menunjukkan model pembelajaran scientific approach dapat memberikan pengaruh yang positif terhadap motivasi belajar siswa. Berdasarkan bukti nyata tersebut dapat disimpulkan bahwa siswa lebih tertarik untuk mengikuti proses pembelajaran dengan scientific approach berbantuan penilaian formatif. Hal ini menunjukkan pengaruh model pembelajaran scientific approach berbantuan penilaian formatif dapat memberikan motivasi dalam belajar sehingga siswa lebih aktif dalam mengikuti kegiatan pembelajaran. Hal ini sejalan dengan teori Piaget bahwa pengetahuan itu akan bermakna manakala dicari dan ditemukan sendiri oleh siswa. Hal ini sesuai dengan teori behavioristik bahwa belajar merupakan perubahan tingkah laku sebagai akibat dari adanya interaksi stimulus dan respon. Selain itu, keterlibatan aktif siswa dalam model pembelajaran scientific approach berbantuan penilaian formatif dapat membantu siswa dalam mengolah informasi/materi pelajaran, sehingga siswa dapat dengan mudah memahami maupun mengingat.

Hasil penelitian ini memperkuat penelitian yang dilakukan oleh Sumayasa dkk (2015) yang menemukan bahwa motivasi belajar siswa yang mengikuti model pembelajaran saintifik hasilnya lebih baik daripada motivasi belajar siswa yang mengikuti model pembelajaran konvensional. Selain itu juga memperkuat hasil penelitian N. S Intani dkk (2016) yang menemukan bahwa adanya penilaian selama pembelajaran atau penilaian formatif mampu meningkatkan motivasi belajar siswa.

Berdasarkan hasil uji Independent Sample T, diketahui bahwa terdapat perbedaan hasil belajar antar siswa pada kelas yang diajar dengan menggunakan model pembelajarn scientific approach berbantuan penilaian formatif dengan kelas yang diajar dengan metode konvensional. Hal ini ditunjukkan melalui uji t nilai posttest (kemampuan akhir) pada kedua kelas penelitian yang menghasilkan nilai probabilitas lebih kecil dari batas nilai sig, sehingga dapat disimpulkan bahwa terhadap pengaruh model pembelajarn scientific approach berbantuan penilaian formatif terhadap hasil belajar siswa pada mata pelajaran Fisika. Perbedaan hasil belajar antara kelas kelas control dan kelas eksperimen dalam penelitian ini disebabkan oleh penggunaan media pembelajaran yang berbeda. Pada kelas eksperimen, pembelajaran dengan menggunakan scientific approach berbantuan penilaian formatif sebagai alat bantu guru dalam menyajikan materi. Berbeda dengan kelas control, pembelajaran konvensional yang memanfaatkan media Power Point dan LKS seperti digunakan guru pada pertemuan-pertemuan sebelumnya. Penggunaan model pembelajaran scientific approach berbantuan penilaian formatif berpengaruh dalam pengaplikasian media pembelajaran dalam proses belajar mengajar. Hal ini ditunjukkan dengan peningkatan hasil belajar yang terjadi pada kelas eksperimen.

Hasil dari penelitian ini memperkuat penelitian yang dilakukan oleh Hidayati dan Endryansyah (2014) yang menemukan bahwa pendekatan ilmiah mampu meningkatkan hasil belajar siswa penggunaan. Selain itu juga mendukung penelitian Hardianti dkk (2015) yang menemukan bahwa terdapat perbedaan hasil belajar fisika yang signifikan antara peserta didik yang diajar dengan dengan pendekatan scientific dan yang diajar dengan pendekatan ekspositori dimana hasil belajar siswa yang diajar dengan menggunakan pendekatan scientific lebih tinggi. Oleh karena itu dapat dikemukakan bahwa model pembelajaran scientific approach berbantuan penilaian formatif berpengaruh terhadap hasil belajar siswa. 
Selama ini sudah banyak penelitian tentang model pembelajaran scientific approach namun pada penelitian ini ditekankan pada perpaduan antara model pembelajaran scientific approach dengan penilaian formatif guna meningkatkan motivasi belajar dan hasil belajar siswa berjenis kelamin perempuan pada mata pelajaran Fisika. Sehingga diharapkan peneliti berikutnya untuk lebih komprehensif lagi dalam melakukan penelitian pada level yang berbeda jenis kelamin yang heterogen karena terbukti berpengaruh dan dapat meningkatkan motivasi belajar dan hasil belajar siswa.

\section{SIMPULAN}

Berdasarkan dari hasil analisis data dan penelitian, maka dapat diperoleh temuan sebagai berikut: Terdapat pengaruh model pembelajaran scientific approach berbantuan penilaian formatif terhadap motivasi belajar Fisika pada siswa kelas XI pada Madrasah Aliyah Negeri 1 Kota Malang. Terdapat pengaruh model pembelajaran scientific approach berbantuan penilaian formatif terhadap hasil belajar Fisika pada siswa kelas XI pada Madrasah Aliyah Negeri 1 Kota Malang.

Berdasarkan kesimpulan dari paparan data yang diperoleh selama melakukan penelitian, penulis mengemukakan beberapa saran guna lebih mengoptimalkan pembelajaran fisika sebagai berikut. Pertama, perlu melakukan penelitian yang lebih komprehensif pada berbagai level tingkat pendidikan karena pelajaran Fisika diajarkan mulai dari Sekolah Menengah Pertama, Sekolah Menengah Atas sampai ke Perguruan Tinggi. Kedua, penelitian ini diharapkan dapat menjadi referensi dan kajian empiris bagi peneliti selanjutnya mengenai model pembelajaran dan dijadikan pedoman dalam memilih pendekatan pembelajaran guna meningkatkan motivasi belajar dan hasil belajar siswa.

\section{DAFTAR RUJUKAN}

Adeyemo, S. A. (2010). Teaching/Learning Physics in Niegerian Secondary School: The Curiculum Transformation, Issues, Problem, and Prospect. International Journal of Educational Research and Technology, 1(1), 99-111

Azizah, R., Yuliati, L., \& Latifah, E. (2015). Kesulitan Pemecahan Masalah Fisika pada Siswa SMA. Jurnal Penelitian Fisika dan Aplikasinya, 5(2), 44-50. http://dx.doi.org/10.26740/jpfa.v5n2.p44-50

Ediyanto, E. (2015). Pengembangan Model Penilaian Formatif Berbasis Web untuk Meningkatkan Pemahaman Konsep Fisika. Jurnal Pendidikan Sains, 2(2), 63-75. https://doi.org/10.17977/jps.v2i2.4499

Istyowati, A., Kusairi, S., \& Handayanto, S. K. (2017). Analisis Pembelajaran dan Kesulitan Siswa SMA Kelas XI terhadap Penguasaan Konsep Fisika. Prosiding Seminar Nasional III Tahun 2017, 237-243.

Hardianti., Nurhayati., \& Yani, A. (2015). Peranan Pendekatan Scientific terhadap Hasil Belajar Fisika Peserta Didik Kelas X SMA Negeri 1 Lappariaja. Jurnal Sains dan Pendidikan Fisika, 11(1), 34-39.

In'am, A., \& Hajar, S. (2017). Learning Geometry Through Discovery Learning using a Scientific Approach. International Journal of Instruction, 10 (1)

Ismail, M. I. (2015). Pengaruh Bentuk Penilaian Formatif terhadap Hasil Belajar IPA Setelah Mengontrol Pengetahuan Awal Siswa. Biotel, 3(2), 175-191.

Nurfaizah., Farhan, A., \& Soewarno. (2017). Pelaksanaan Pendekatan Scientific pada Pembelajaran Fisika di SMA Negeri di Kabupaten Pidie. Jurnal Ilmiah Mahasiswa Pendidikan Fisika, 2(3), 299-302.

Nursyarifah, R., Rochman, C., Nasrudin, D., \& Yuningsih, E. K. (2018). Efektivitas Proses Pembelajaran Fisika Menggunakan Pendekatan Saintifik. Wahana Pendidikan Fisika, 3(2), 13-18.

Rhosalia, L. A. (2017). Pendekatan Saintifik (Scientific Approach), Pembelajaran Tematik Terpadu, Kurikulum 2013 versi 2016, 1(1), 59-77. https://doi.org/10.4236/aim.2012.24065

Samudra, G. B., Suastra, I. W., \& Suma, K. (2014). Permasalahan-Permasalahan yang Dihadapi Siswa SMA di Kota Singaraja dalam Mempelajari Fisika. E-Journal Program Pascasarjana Universitas Pendidikan Ganesha, 4(1), 1-7.

Sari, N., \& Sunarno, W. (2018). Sekolah Menengah Atas the Analysis of Students Learning Motivation on Physics Learn- Ing in Senior Secondary School, 3, 17-32.

Sumayasa, I. N., Marhaeni, N., \& Dantes, N. (2015). Pengaruh Implementasi Pendekatan Saintifik terhadap Motivasi Belajar dan Hasil Belajar Bahasa Indonesia pada Siswa Kelas VI di Sekolah Dasar se Gugus VI Kecamatan Abang Karangasem. E- Journal Program Pascasarjana Universitas Pendidikan Ganesha, 5, 1-11.

Wina, D. R., Hindarto, N., \& Prasetyo, A. P. B. (2017). Studi Kasus Pendekatan Saintifik dalam Pembelajaran IPA pada Kurikulum 2013 di SMP Negeri 5 Semarang. Journal of Innovative Science Education, 01(01), 17-27. 